\title{
Low melt fluxes enhance differentiation and complexity of intraplate volcanic plumbing systems

\author{
AL-TAMINI TAPU ${ }^{1 *}$, TERESA UBIDE ${ }^{1}$, PAULO
} VASCONCELOS $^{1}$
}

${ }^{1}$ School of Earth and Environmental Sciences, The University of Queensland, Australia (*correspondence:

a.tapu@uq.edu.au)

Eastern Australia hosts the world's longest belt of hotspot-derived continental intraplate volcanoes, with a southward-younging trend ( $34 \mathrm{Ma}$ to $6 \mathrm{Ma}$ ) that has been linked to the motion of the Australian plate over one or several stationary mantle plumes. Here we apply statistical analysis to geochronological, volcanological, and petrological data across the age-progressive track to investigate long-term tempos of melt transport and eruption and their implications for the development of volcanic systems in intraplate settings.

${ }^{40} \mathrm{Ar} /{ }^{39} \mathrm{Ar}$ ages reveal that the lifespan of volcanic activity is bimodal, and splits volcanoes north and south of Tweed volcano, where anomalously voluminous activity has been linked to a period of slow plate motion. In the northern segment, "long-lived" volcanoes were emplaced over ca. 3 to 5 million years. To the south, "short-lived" volcanoes were active for 1 million years or less.

The volume of erupted material and interestingly, the petrology of the flows and their crystal cargo appear to correlate with the duration of volcanism. Long-lived volcanoes erupted very high volumes $\left(>800 \mathrm{~km}^{3}\right)$ of magma that was dominantly basaltic in composition and contained phenocrysts with relatively simple zonations. In contrast, short-lived volcanoes erupted typically $<300 \mathrm{~km}^{3}$ and contained higher proportions of silicic lavas and basalts with complexly zoned phenocrysts.

Our data suggest that sustained melt fluxes promoted direct delivery of mantle-derived magmas, whereas shorter melt fluxes enhanced magma storage in the crust and the development of complex plumbing systems. If younger canters record waning plume activity with time, it follows that weakening-dying plumes might result in increasingly complex feeder systems. 